DOI: $10.19195 / 0137-1134.118 .8$

\title{
DELEGOWANIE PRACOWNIKÓW W RAMACH ŚWIADCZENIA USŁUG. ROLA PAŃSTWOWEJ INSPEKCJI PRACY JAKO ORGANU WŁAŚCIWEGO W ROZUMIENIU „DYREKTYWY WDROŻENIOWEJ” 2014/67/UE ORAZ INNE ZADANIA PAŃSTWOWEJ INSPEKCJI PRACY W ZAKRESIE DELEGOWANIA PRACOWNIKÓW
}

\begin{abstract}
Abstrakt: Artykuł jest próbą przybliżenia czytelnikowi instytucji delegowania pracowników w ramach świadczenia usług, ze szczególnym zwróceniem uwagi na różnice między owym delegowaniem a podróżą służbową. Wydaje się, że wyjaśnienie tych różnic ma niebagatelne znaczenie w wypadku delegowania pracowników z terenu RP do pracy za granicę, gdyż zastosowanie procedur odnoszących się do podróży służbowej w miejsce rzeczywistego delegowania prowadzi w konsekwencji często do - świadomego i celowego bądź zupełnie przypadkowego — obchodzenia przepisów z zakresu ubezpieczeń społecznych oraz podatku dochodowego od osób fizycznych, a tym samym do uszczuplenia należnych wpływów do budżetu państwa.

W opracowaniu przedstawiono też — nierozerwalnie związaną z delegowaniem — problematykę minimalnych warunków zatrudnienia kraju przyjmującego, które bez względu na wybór prawa dokonany przez strony stosunku prawnego muszą zostać zapewnione przez pracodawcę delegującego pracownika do pracy poza granicami kraju, w którym zwykle tę pracę wykonuje.

Delegowanie pracowników w ramach świadczenia usług jest obszarem prawa pracy regulowanym przez normy wewnątrzwspólnotowe, które zostały implementowane do polskiego porządku prawnego. W artykule omówiono najważniejsze unijne akty prawne regulujące tę tematykę oraz wskazano, w jaki sposób przepisy te zostały wprowadzone do polskiego prawa ustawą z dnia 10 czerwca 2016 roku o delegowaniu pracowników w ramach świadczenia usług.

Dokonując analizy zapisów przywołanej ustawy, odniesiono się do przydzielonych jej przepisami kompetencji Państwowej Inspekcji Pracy jako „organu właściwego” w rozumieniu dyrektywy wdrożeniowej 2014/67/UE, jak i innych zadań, obowiązków i uprawnień tego urzędu, wynikających $\mathrm{z}$ owych aktów prawnych w zakresie delegowania pracowników w ramach świadczenia usług.

Poczynione w artykule rozważania, przedstawione na tle aktualnego stanu prawnego, prowadzą do wniosków w zakresie niezbędnych zmian przepisów dotyczących uprawnień i kompetencji Państwowej Inspekcji Pracy jako organu, który wyznaczony został do dbania o praworządność w obszarze delegowania pracowników.
\end{abstract}

Słowa kluczowe: delegowanie pracowników, warunki zatrudnienia, biuro łącznikowe i organ właściwy, współpraca administracyjna, kontrole 


\section{WPROWADZENIE}

Polacy wykorzystali szansę, jaką otworzyło przed naszym krajem podpisanie w 2003 roku traktatu akcesyjnego i wejście 1 maja 2004 roku Polski do Unii Europejskiej. Choć w początkowym okresie jedynie trzy kraje dawały polskim obywatelom nieograniczoną możliwość podjęcia w nich pracy (Szwecja, Irlandia i Wielka Brytania), a pozostałe na 7 lat znacznie ograniczyły możliwość zarobkowej emigracji, to instytucja delegowania pracowników pozwoliła pokazać, że jakość świadczonych przez polskich przedsiębiorców usług, a także ich cenowa konkurencyjność mogą stanowić o ich przewadze na europejskich rynkach, a także być głównym stymulantem rozwoju gospodarczego. Po 15 latach funkcjonowania we wspólnej europejskiej rzeczywistości rozszerzenie Wspólnoty o 10 nowych krajów staje się przyczyną pęknięć i rozłamów. Państwa „starej Unii” zaczynają walczyć z konkurencyjnością przedsiębiorców pochodzących z państw, które powiększyły Unię na podstawie traktatu ateńskiego, poprzez coraz dalej idące działania protekcjonistyczne. W działaniach tych, również w postaci restrykcyjnych i niewspółmiernych kontroli organów takich jak inspekcje pracy, przodują Francja i Belgia ${ }^{1}$.

Osią konfliktu między państwami „starej” i „,nowej” Unii stało się właśnie delegowanie pracowników. Pod hasłem walki z „dumpingiem socjalnym” następuje ograniczanie swobody świadczenia usług. Konkurencyjność usługodawców z Europy Środkowo-Wschodniej została znacznie osłabiona nowelizacją dyrektywy Parlamentu Europejskiego i Rady 96/71/WE z dnia 16 grudnia 1996 roku dotyczącej delegowania pracowników w ramach świadczenia usług ${ }^{2}$. I tak delegowanie pracowników zamiast być głównym narzędziem konwergencji staje się przyczyną pogłębiających się różnic, a w konsekwencji może być przyczynkiem do potęgowania się gospodarczych dysproporcji.

\section{POJĘCIE I IDEA DELEGOWANIA PRACOWNIKÓW}

Swoboda przemieszczania się pracowników, ustanowiona art. 45 Traktatu o funkcjonowaniu Unii Europejskiej (dawniej art. 39 traktatu WE) ${ }^{3}$, może być zasadniczo realizowana trzema drogami:

${ }^{1}$ Czytaj więcej w Ł. Osiński, Protekcjonizm zachodniej Europy w kończącej się kadencji PE podzielit UE, Polska Agencja Prasowa, https://www.pap.pl/aktualnosci/news,457657,protekcjonizm-zachodniej-europy-w-konczacej-sie-kadencji-pe-dzielil-ue.html?fbclid=IwAR0kNq28ucah6K9U ND4Y8mW9mjmt0Y93g3A6r-NugSVSwYfN2Ita4gNPs7A (dostęp: 23.05.2019).

2 Dz. Urz. WE L 18 z 21 stycznia 1997 r., s. 1; Dz. Urz. UE, polskie wydanie specjalne, rozdz. 5, t. 2, s. 431, dalej: dyrektywa podstawowa lub dyrektywa 96/71/WE.

3 Wersje skonsolidowane Traktatu o Unii Europejskiej i Traktatu o funkcjonowaniu Unii Europejskiej, Dz. Urz. UE C 202 z 2016 r., t. 56 z 7 czerwca 2016 r., dalej: TFUE. 
— migracji zarobkowej — pracownik z jednego kraju członkowskiego podejmuje zatrudnienie w przedsiębiorstwie działającym w innym kraju członkowskim, przenosząc najczęściej swoje centrum interesów życiowych do tego kraju, a jego zatrudnienie opiera się w całości na systemie prawnym kraju świadczenia pracy;

— transgranicznego świadczenia pracy — pracownik jednego kraju członkowskiego świadczy pracę na terenie innego kraju członkowskiego, jednak praca ta nie jest związana $\mathrm{z}$ realizacją usługi na rzecz przedsiębiorstwa $\mathrm{z}$ kraju przyjmującego, a zatrudnienie opiera się w całości na systemie prawnym kraju wysyłającego;

— delegowania pracowników w ramach świadczenia usług.

Przepisy polskiego prawa nie definiują pojęcia „delegowanie”. Wciąż bardzo często mylnie uważa się je za tożsame skierowaniu pracownika w podróż służbową. Choć w rzeczywistości obie sytuacje są związane z wykonywaniem pracy poza siedzibą pracodawcy, obie mogą dotyczyć pracy poza granicami kraju, to jednak nie są tą samą instytucją prawną. Delegowanie do pracy poza granicami kraju jest czasową zmianą stałego miejsca wykonywania pracy, a nie poleceniem pracownikowi wykonania pracy poza miejscem stałego jej świadczenia. Należy również pamiętać, że obie te sytuacje mają odmienne dla pracownika konsekwencje w zakresie zobowiązań publicznoprawnych ${ }^{4}$, a także mogą powodować między innymi obniżenie świadczeń otrzymywanych z tytułu wykonywania pracy.

Podróż służbowa została zdefiniowana w art. $77^{5} \S 1$ kodeksu pracy, który stanowi, że podróżą służbową jest wykonywanie — na polecenie pracodawcy zadania służbowego poza miejscowością, w której znajduje się siedziba pracodawcy, lub poza stałym miejscem pracy. Definicja ta wskazuje, że podróż służbowa ma charakter incydentalny, a zadanie służbowe wykonywane poza miejscowością siedziby pracodawcy bądź poza stałym miejscem pracy musi być skonkretyzowane i nie może mieć charakteru generalnego ${ }^{5}$. Nie jest więc podróżą służbową wykonywanie normalnej pracy, to jest czynności objętych podstawowym zakresem czynności służbowych ${ }^{6}$. Podróż służbowa charakteryzuje się tym, że w kompleksie obowiązków pracownika jest zjawiskiem nietypowym, okazjonalnym? ${ }^{7}$.

Choć przepisy prawa pracy (a także przepisy prawa podatkowego i ubezpieczeń społecznych) nie wskazują maksymalnego okresu trwania podróży służbowej, to owa nietypowość podróży, jej okazjonalny i incydentalny charakter, świadczy również o tym, że — poza wyjątkami, w których wykonywanie pracy wiąże się z ciągłym przemieszczaniem się (na przykład kierowcy, przedstawiciele

4 Por. wyrok Sądu Najwyższego z dnia 14 listopada 2013 roku, II UK 204/13, http://www. sn.pl/sites/orzecznictwo/orzeczenia3/ii\%20uk\%20204-13-1.pdf (dostęp: 28.10.2019).

5 Por. uchwała Sądu Najwyższego z dnia 19 listopada 2008 roku, II PZP 11/08, http://www. sn.pl/sites/orzecznictwo/orzeczenia1/ii\%20pzp\%2011-08.pdf (dostęp: 28.10.2019).

6 Wyrok Sądu Najwyższego z dnia 22 lutego 2008 roku, I PK 208/07, http://www.sn.pl/sites/ orzecznictwo/orzeczenia1/i\%20pk\%20208-07-1.pdf (dostęp: 28.10.2019).

7 Wyrok Sądu Najwyższego z dnia 3 grudnia 2009 roku, II PK 138/09, http://www.sn.pl/sites/ orzecznictwo/orzeczenia2/ii\%20pk\%20138-09-1.pdf (dostęp: 28.10.2019). 
handlowi) — podróż służbowa nie może mieć charakteru permanentnego, a czas jej trwania musi być z góry określony, adekwatny do czasu, jaki jest niezbędny do wykonania konkretnego celu służbowego, dla którego podróż jest odbywana, i wskazany przez pracodawcę w wydanym poleceniu podróży.

Jak już wspominano na wstępie, polskie prawo nie zawiera definicji delegowania, jednak z samej istoty tej instytucji można wywieść istotne różnice w stosunku do pojęcia podróży służbowej. Pomocna może być tu również definicja pracownika delegowanego, pojawiająca się w dyrektywie podstawowej czy ustawie o delegowaniu. $\mathrm{W}$ definicji sformułowanej w polskim akcie prawnym wskazuje się (zarówno w wypadku definicji pracownika delegowanego z terytorium RP, jak i delegowanego do Polski), że pracownikiem tym jest ,pracownik [...] tymczasowo skierowany do pracy na terytorium (tu odpowiednio)". Oznacza to, że pracownik delegowany zostaje skierowany przez swojego pracodawcę do wykonywania pracy, a nie do realizacji konkretnego, okazjonalnego zadania, co jednocześnie przesądza, że nie mamy tu do czynienia z podróżą służbową. W wypadku delegowania następuje bowiem okresowa zmiana miejsca wykonywania normalnej, objętej zakresem czynności służbowych, pracy. Tym samym zmiana ta, jako zmiana warunków umowy, nastąpić musi bądź za zgodną wolą obu stron w drodze porozumienia, bądź w wyniku wypowiedzenia pracownikowi dotychczasowych warunków umowy o pracę.

Dla instytucji delegowania charakterystyczne jest ponadto, iż owo wykonywanie pracy wiąże się ze świadczeniem usług, które realizowane są na podstawie umowy zawartej pomiędzy pracodawcą delegującym a zagranicznym kontrahentem. Brak usługi transgranicznej, czyli usługi świadczonej na rzecz podmiotu prowadzącego działalność na terytorium innego państwa członkowskiego, stanowi o braku podstaw do uznania takiego skierowania do pracy za granicę za delegowanie w rozumieniu dyrektywy 96/71/WE.

Dyrektywa podstawowa definiuje pojęcie pracownika delegowanego jako pracownika, który przez ograniczony okres wykonuje swoją pracę na terytorium innego państwa członkowskiego niż państwo, w którym zwyczajowo pracuje ${ }^{8}$, przy czym - co niezmiernie ważne - przyjmuje się tę definicję pracownika, którą stosuje się w państwie przyjmującym ${ }^{9}$. W wypadku prawa polskiego badanie sytuacji prawnej osoby delegowanej na teren RP będzie się opierało na wykładni art. $22 \S 1$ kodeksu pracy, wskazującego przesłanki uznania danego stosunku za stosunek pracy. Jednak niewypełnienie w przeważającym stopniu owych przesłanek wobec polskiego zleceniodawcy delegowanego do wykonywania pracy na terytorium innego państwa członkowskiego nie będzie oznaczało, że przedsiębiorca delegujący, pomimo wyboru przez strony tego stosunku prawa polskiego, nie będzie zobowiązany do zastosowania wobec osoby delegowanej przepisów

8 Art. 2 pkt 1 dyrektywy 96/71/WE.

9 Art. 2 pkt 2 dyrektywy 96/71/WE. 
wymuszających swoje stosowanie odnoszących się do pracowników najemnych, gdyż pojęcie „pracownika” oceniane będzie w rozumieniu przepisów krajowych państwa przyjmującego. Oznacza to między innymi, że działania polskich przedsiębiorców, mające na celu obniżenie zobowiązań publicznoprawnych i pracowniczych poprzez odejście od zatrudnienia pracowniczego na rzecz powierzenia pracy na podstawie prawa cywilnego, mogą się okazać bezcelowe i nieskuteczne w wypadku transgranicznego świadczenia usług.

Choć definicja pracownika delegowanego w ramach świadczenia usług weszła oficjalnie do polskiego porządku prawnego wraz z uchwaleniem ustawy z dnia 10 czerwca 2016 roku o delegowaniu pracowników w ramach świadczenia usług ${ }^{10}$, to delegowanie pracowników jako takie było już polskim przedsiębiorcom znane w praktyce od dnia wstąpienia Polski do Unii Europejskiej, gdy zaczęto wykorzystywać jedną z podstawowych wspólnotowych zasad, jaką jest swoboda przemieszczania się i swoboda świadczenia usług.

Przed uchwaleniem ustawy o delegowaniu pracowników postanowienia dyrektywy 96/71/WE były obecne w polskim prawie w rozdziale IIa kodeksu pracy pt. Warunki zatrudnienia pracowników skierowanych do pracy na terytorium Rzeczypospolitej Polskiej z państwa będącego członkiem Unii Europejskiej.

Dyrektywę podstawową stosuje się do tych przedsiębiorstw prowadzących działalność w jednym państwie członkowskim (państwo wysyłające), które w ramach świadczenia usług poza tym państwem kierują swoich pracowników na terytorium innego państwa członkowskiego (państwo przyjmujące). Owo kierowanie może się odbywać w trzech formach:

— gdy przedsiębiorca deleguje pracowników, którzy pod jego kierownictwem będą realizować usługę na podstawie umowy zawartej pomiędzy tym przedsiębiorcą a odbiorcą usługi działającym w przyjmującym państwie członkowskim (tak zwana usługa eksportowa), pod warunkiem że przez cały okres delegowania między przedsiębiorcą a pracownikiem istnieje stosunek pracy;

— gdy delegowanie pracowników ma miejsce do zakładu powiązanego, oddziału przedsiębiorstwa bądź przedsiębiorstwa należącego do tej samej grupy przedsiębiorstw (tak zwane delegowanie wewnątrzkorporacyjne), także pod warunkiem że przez cały okres delegowania będzie istniał stosunek pracy między przedsiębiorstwem wysyłającym a pracownikiem delegowanym;

— jako przedsiębiorstwo pracy tymczasowej lub agencja wynajmująca personel wynajmuje pracownika przedsiębiorstwu prowadzącemu działalność gospodarczą lub działającemu na terytorium innego państwa członkowskiego, o ile przez cały okres delegowania istnieje stosunek pracy pomiędzy przedsiębiorstwem pracy tymczasowej lub agencją wynajmującą a pracownikiem.

Podstawową przesłanką uznania świadczenia pracy poza granicami macierzystego kraju pracownika za jego delegowanie w ramach świadczenia usług jest

10 Tekst jedn. Dz.U. z 2018 r. poz. 2206, dalej: ustawa o delegowaniu pracowników. 
fakt nieprzerwanego istnienia rzeczywistej więzi prawnej między przedsiębiorcą wysyłającym a osobą skierowaną do pracy za granicą oraz fakt realizowania przez przedsiębiorstwo wysyłające usługi na rzecz przedsiębiorstwa funkcjonującego w kraju przyjmującym. Jeżeli więź ta zostanie przerwana, na przykład poprzez rzeczywiste wykonywanie pracy na rzecz i odpowiedzialność przedsiębiorstwa, dla którego realizowana jest usługa, nie będzie podstaw do stosowania przepisów dyrektywy o delegowaniu pracowników.

\section{MINIMALNE WARUNKI ZATRUDNIENIA}

Dyrektywa o delegowaniu pracowników wskazuje siedem podstawowych warunków zatrudnienia, stanowiących jądro bezwzględnie obowiązujących przepisów zapewniających minimalną ochronę ${ }^{11}$ pracowników delegowanych, które nie mogą być jednocześnie rozumiane jako ograniczenie ich praw. Warunki te zostały ustalone w celu ochrony bogatszych rynków przed napływem taniej siły roboczej (dumping społeczny), a jednocześnie są zabezpieczeniem pracowników delegowanych przed niezapewnieniem im przez delegujących ich pracodawców warunków zatrudnienia pozwalających między innymi na utrzymanie się w kraju przyjmującym w okresie delegowania.

Warto zauważyć, że swoboda przemieszczania się pracowników oparta jest w Unii Europejskiej na równym traktowaniu pracowników rodzimych i migrujących, co gwarantuje art. 45 TFUE (,Swoboda ta obejmuje zniesienie wszelkiej dyskryminacji ze względu na przynależność państwową między pracownikami Państw Członkowskich w zakresie zatrudnienia, wynagrodzenia i innych warunków pracy”). Zasada równego traktowania nie ma jednak zastosowania do pracowników delegowanych, gdyż dyrektywa o delegowaniu pracowników opiera swoje funkcjonowanie na swobodzie świadczenia usług (art. 56 TFUE), co powoduje odmienne traktowanie pracowników delegowanych od pracowników rodzimych. Jak zauważa Leszek Mitrus ${ }^{12}$, ustawodawca europejski nie skorzystał z kompetencji traktatowych w zakresie ochrony praw pracowniczych. Wprowadzając maksymalną granicę wymagań, która może zostać ustanowiona przez państwa członkowskie wobec przedsiębiorstw delegujących pracowników, dyrektywa jest swoistego rodzaju ochroną nie dla pracowników delegowanych, lecz dla usługodawców korzystających ze swobody świadczenia usług ${ }^{13}$. Co znamienne właśnie dla instytucji delegowania, dyrektywa 96/71/WE, wprowadzając standard minimalnych warunków zatrudnienia, ustanawia

11 Zob. motyw 13 dyrektywy podstawowej.

12 L. Mitrus, Charakter prawny delegowania pracowników w ramach swobody świadczenia ustug w Unii Europejskiej, „Europejski Przegląd Sądowy” czerwiec 2018, s. 5.

13 Ibidem, s. 8. 
go jednocześnie maksymalnym poziomem ochrony pracowników delegowanych ${ }^{14}$. Oznacza to, że państwa członkowskie nie mogą swoimi jednostronnymi działaniami wprowadzić jako bezwzględnie obowiązujących przepisów zapewniających wyższy standard ochrony pracowniczej ${ }^{15}$.

Zasadniczo stosunek pracy pracownika delegowanego podlega prawu, które strony wybrały, a w wypadku braku takiego prawa — prawu kraju, na terenie którego lub z którego najczęściej pracownik świadczy pracę bądź kraju siedziby pracodawcy. Jednakże bez względu na to, jakiego wyboru dokonano w zakresie prawa rządzącego umową, w wypadku delegowania pracownika na terytorium innego państwa będą miały do niego zastosowanie przepisy państwa przyjmującego w następującym zakresie:

— maksymalnych okresów pracy i minimalnych okresów odpoczynku;

- minimalnego wymiaru płatnych urlopów wypoczynkowych;

- minimalnych stawek płacy wraz ze stawką za nadgodziny;

— warunków wynajmu pracowników, w szczególności przez przedsiębiorstwa zatrudnienia tymczasowego;

- zdrowia, bezpieczeństwa i higieny w miejscu pracy;

— środków ochronnych stosowanych w odniesieniu do warunków zatrudnienia kobiet ciężarnych lub kobiet tuż po urodzeniu dziecka oraz pracy dzieci i młodzieży;

— równości traktowania mężczyzn i kobiet, a także innych przepisów w zakresie niedyskryminacji.

Minimalne warunki zatrudnienia muszą wynikać z przepisów prawnych, rozporządzeń lub przepisów administracyjnych i/lub umów zbiorowych, lub orzeczeń arbitrażowych uznanych za powszechnie obowiązujące w rozumieniu art. 3 ust. 8 dyrektywy podstawowej, o ile dotyczą one rodzajów działalności wymienionych w załączniku do niej (to jest prac związanych z budową, naprawą, utrzymaniem, przeróbką lub rozbiórką budowli).

Artykuł 3 ust. 7 dyrektywy 96/71/WE pozwala na odstąpienie od wymuszających swoje zastosowanie przepisów państwa przyjmującego w sytuacji gdy zapewniają one mniejszą ochronę niż prawo właściwe dla stosunku pracy na zasadach ogólnych. Minimalnych warunków zatrudnienia państwa oddelegowania nie trzeba stosować także w przypadku gdy strony umowy — nawet jeżeli prawo nią rządzące przewiduje mniej korzystne warunki — ustaliły jej postanowieniami warunki, które zapewniają pracownikowi dalej idącą ochronę.

14 M. Tomaszewska Delegowanie pracowników - w poszukiwaniu równowagi między swobodą świadczenia ustug a ochroną praw pracownika”, „Europejski Przegląd Sądowy” czerwiec 2018, s. 25.

15 Por. tak zwana sprawa de Laval — wyrok Trybunału Sprawiedliwości z dnia 18 grudnia 2007 roku, C-341/05, Laval un Partneri przeciwko Svenska Byggnadsarbetareförbundet, Svenska Byggnadsarbetareförbundets avdelning 1, Byggettan i Svenska Elektrikerförbundet, EU:C:2007:809, pkt 59. 
Państwa członkowskie mogą wprowadzić pewne odstępstwa od tych zasad w kwestiach:

- minimalnych stawek płacy w wypadku prac trwających maksymalnie miesiąc, o ile prace te nie są wykonywane przez pracowników delegowanych przez agencję zatrudnienia;

- minimalnych stawek płacy i minimalnego wymiaru urlopu w wypadku realizacji prac o małym zasięgu (pod warunkiem że prace te nie są realizowane przez agencję udostępniającą pracowników).

Minimalnych stawek płacy oraz minimalnego wymiaru płatnego urlopu wypoczynkowego nie stosuje się, z mocy samej dyrektywy, w wypadku usług polegających na wstępnym montażu i/lub pierwszej instalacji wyrobów stanowiących nieodłączną część umowy na dostawę wyrobów, a które są niezbędne do uruchomienia dostarczonych wyrobów i wykonywane przez wykwalifikowanych i/lub wyspecjalizowanych robotników z przedsiębiorstwa dostawczego, jeśli okres delegowania nie przekracza ośmiu dni. Wyłączenie nie ma zastosowania do usług wskazanych w załączniku do dyrektywy (usług branży budowlanej).

W obowiązującym jeszcze brzmieniu dyrektywy podstawowej pracodawca delegujący jest zobowiązany do zapewnienia pracownikowi delegowanemu minimalnej stawki płacy oraz stawki za pracę w godzinach nadliczbowych obowiązujących w państwie przyjmującym. Jednakże w wyniku dążenia państw „starej” Unii do stosowania wobec pracowników delegowanych zasady równego traktowania w wyniku rewizji dyrektywy podstawowej dokonano między innymi zmiany zapisu art. 3 ust. 1 lit. c, wprowadzając w miejsce dotychczasowego zapisu o „minimalnych stawkach płacy, wraz ze stawką za nadgodziny” obowiązek zapewnienia pracownikowi delegowanemu obowiązującego $\mathrm{w}$ państwie przyjmującym „wynagrodzenia wraz ze stawką za godziny nadliczbowe"16. Jednak do 30 lipca 2020 roku zastosowanie będzie miała nadal dyrektywa w 96/71/WE w brzmieniu sprzed uchwalenia zmian. Oznacza to, że do dnia wejścia w życie przepisów zmienionych dyrektywą 2018/957 przedsiębiorcy delegujący zobowiązani są do zapewnienia pracownikom delegowanym minimalnych warunków zatrudnienia wskazanych w art. 3 ust. 1 dyrektywy podstawowej, w tym minimalnej stawki płacy wraz ze stawką za nadgodziny.

16 Dyrektywa Parlamentu Europejskiego i Rady 2018/957 z dnia 28 czerwca 2018 roku zmieniająca dyrektywę 96/71/WE dotyczącą delegowania pracowników w ramach świadczenia usług, Dz.U. UE L z 2018 r., 173/16, wydanie polskie, s. 6, dalej: dyrektywa zmieniająca lub dyrektywa 2018/957. 


\section{USTAWA O DELEGOWANIU PRACOWNIKÓW W RAMACH ŚWIADCZENIA USŁUG}

Przez lata funkcjonowania dyrektywy podstawowej, a szczególnie po rozszerzeniu Unii Europejskiej, gdy to kraje „nowej Unii” stały się liderami w transgranicznym świadczeniu usług, okazało się, że rozwiązania zawarte w postanowieniach dyrektywy podstawowej są niewystarczające dla ochrony pracowników delegowanych przed nadużyciami ze strony tych przedsiębiorców, którzy nie przestrzegali ustanowionych reguł transgranicznego świadczenia usług. Ponadto zarówno przedsiębiorcy delegujący, jak i pracownicy delegowani podkreślali brak dostępu do informacji na temat minimalnych warunków zatrudnienia obowiązujących w państwach członkowskich. Pracodawcy delegujący uskarżali się także na brak informacji o obowiązkach administracyjnych ciążących na nich w związku $\mathrm{z}$ delegowaniem pracowników do czasowego wykonywania pracy poza granicami swojego kraju.

Problemy związane z realizacją dyrektywy 96/71/WE dotyczyły też działalności podmiotów wykorzystujących niedoskonałości postanowień owego aktu i stosowania różnej maści procederów mających na celu obchodzenie prawa. Najpowszechniejszym z nich, jednocześnie wyjątkowo uciążliwym dla organów kontrolnych poszczególnych krajów członkowskich, jest problem przedsiębiorstw „skrzynek pocztowych”. Praktyka ta polega na zakładaniu przez przedsiębiorstwa, które swą normalną, zwyczajową działalność prowadzą w krajach o wysokich kosztach pracy, przedsiębiorstw w tych krajach, w których obciążenia publicznoprawne są znaczne niższe. Przedsiębiorstwa te zakładane są wyłącznie w celu wysłania pracowników z tego kraju, przy utrzymaniu dla nich jego ustawodawstwa, do kraju macierzystego w celu realizacji normalnie tam prowadzonej działalności. Problemem jest także pozorne samozatrudnienie (w wypadku Polski ten proceder najczęściej dotykał branży usług opiekuńczych) oraz działania mające na celu zaniżenie wypłacanego wynagrodzenia oraz składek na ubezpieczenia społeczne, polegające głównie na bezpodstawnym zastępowaniu instytucji delegowania podróżami służbowymi.

W stosunku do instytucji kontrolnych podnoszony był zarzut nieefektywnej współpracy, długotrwałości prowadzonych postępowań i małej skuteczności z perspektywy interesów pracowników delegowanych, skarżących się na nieprzestrzeganie ich uprawnień związanych z wykonywaniem pracy za granicą.

Widząc potrzebę doprecyzowania regulacji związanych z delegowaniem pracowników w ramach świadczenia usług w związku z obserwowanymi nadużyciami związanymi z delegowaniem ${ }^{17}$, podjęto decyzję o przygotowaniu odrębnej

17 Zob. Komunikat Komisji Europejskiej z dnia 4 kwietnia 2006 roku Wytyczne dotyczace delegowania pracowników w ramach świadczenia ustug" (COM 2006, nr 159). 
dyrektywy, której celem miało być wprowadzenie mechanizmów dla lepszego wdrożenia, stosowania i egzekwowania dyrektywy „podstawowej”18.

Przygotowując tekst nowej dyrektywy, za priorytetowe uznano następujące cele:

— doprecyzowanie elementów pojęcia „delegowanie”;

- poprawę systemu informowania o warunkach zatrudnienia;

— wprowadzenie standardów transgranicznej współpracy administracyjnej;

— określenie katalogu dopuszczalnych środków kontroli;

— wprowadzenie mechanizmów ochrony praw i zabezpieczenia roszczeń pracowniczych;

- opracowanie mechanizmów transgranicznego egzekwowania kar administracyjnych i grzywien nakładanych w związku z naruszeniem przepisów o delegowaniu.

Powyższe cele znalazły swoje odzwierciedlenie w dyrektywie Parlamentu Europejskiego i Rady 2014/67/UE w sprawie egzekwowania dyrektywy 96/71/WE dotyczącej delegowania pracowników w ramach świadczenia usług, zmieniającej rozporządzenie (UE) nr 1024/2012 w sprawie współpracy administracyjnej za pośrednictwem systemu wymiany informacji na rynku wewnętrznym (,rozporządzenie w sprawie IMI") ${ }^{19}$ uchwalonej w dniu 15 maja 2014 roku. Termin implementowania jej postanowień do krajowego porządku prawnego został narzucony państwom członkowskim jej art. 23 ust. 1 i mijał 18 czerwca 2016 roku.

Dyrektywa wdrożeniowa miała dać skuteczniejsze mechanizmy kontroli w obszarze delegowania, narzędzia do oceny nadużyć, których dopuszczają się nieuczciwe podmioty delegujące. Cel ten osiągnięto między innymi przez ustalenie wobec firm delegujących wymogów w zakresie przejrzystości informacji oraz umożliwiania inspekcji.

To właśnie ten termin stał się bezpośrednim powodem podjęcia prac legislacyjnych nad ustawą o delegowaniu pracowników w ramach świadczenia usług. Rzeczpospolita Polska znalazła się w gronie nielicznych krajów UE, które zdołały na czas wprowadzić do krajowego porządku prawnego nowe regulacje prawne dotyczące delegowania pracowników. Sejm uchwalił w dniu 10 czerwca 2016 roku ustawę o delegowaniu pracowników w ramach świadczenia usług.

Należy zaznaczyć, że niniejsza ustawa wdraża nie tylko postanowienia dyrektywy 2014/67/UE, lecz także niektóre postanowienia dyrektywy 96/71/WE, w tym odnoszące się na przykład do minimalnych standardów zatrudnienia gwarantowanych pracownikom delegowanym oraz do współpracy administracyjnej i wymiany informacji w sprawach dotyczących delegowania. Ustawa o delegowaniu pracowników w ramach świadczenia usług ma charakter kompleksowy w tym sensie, że

18 Zob. też Dokument roboczy służb Komisji Impact Assessment. Revision of the legislative framework on the posting of workers in the context of provision of services z dnia 21 marca 2012 roku, SWD(2012) 63, http://ec.europa.eu/social/BlobServlet?docId=7481\&langId=en (dostęp: 28.10.2019).

19 Dz. Urz. UE L 159 z 28 maja 2014 roku, s. 11, dalej: dyrektywa wdrożeniowa lub dyrektywa 2014/67/UE. 
reguluje zarówno zagadnienia dotyczące delegowania pracowników firm zagranicznych, kierowanych do czasowego wykonywania pracy w Polsce, jak i - w zakresie, w jakim jest to możliwe w odniesieniu do przepisów prawa krajowego kwestie delegowania pracowników polskich firm do czasowego wykonywania pracy za granicą. Przepisy, zawarte uprzednio w rozdziale IIa kodeksu pracy Warunki zatrudnienia pracowników skierowanych do pracy na terytorium Rzeczypospolitej Polskiej z państwa będącego członkiem Unii Europejskiej (art. 671-67 k.p.), związane z kierowaniem pracowników zagranicznych do pracy w Polsce zostały uchylone i ,przeniesione" do nowej ustawy o delegowaniu pracowników.

Ustawa o delegowaniu pracowników określa ponadto zasady prowadzenia kontroli przestrzegania przepisów o delegowaniu oraz realizacji obowiązków informacyjnych związanych z delegowaniem pracowników, zasady współpracy z właściwymi organami innych państw członkowskich, ochrony pracowników delegowanych na terytorium RP i z tego terytorium oraz tryb postępowania dotyczącego realizacji wniosków o powiadomienie o decyzji w sprawie nałożenia na pracodawcę delegującego z terytorium RP administracyjnej kary pieniężnej oraz o egzekucji takiej kary lub grzywny.

Ponadto $\mathrm{w}$ ustawie zawarto przepisy karne $\mathrm{z}$ katalogiem wykroczeń związanych z niedopełnieniem obowiązków dotyczących delegowania pracowników zarówno na terytorium Polski, jak i z tego terytorium.

\section{PAŃSTWOWA INSPEKCJA PRACY JAKO „ORGAN WŁAŚCIWY” ORAZ INNE ZADANIA PIP W ZAKRESIE DELEGOWANIA PRACOWNIKÓW}

Regulacja zawarta w przepisach rozdziału IIa kodeksu pracy stanowiła w zasadzie wierne powielenie tekstu dyrektywy 96/71/WE. Choć dyrektywa ta zobowiązywała państwa członkowskie do wprowadzenia do rodzimych systemów prawnych rozwiązań, które zagwarantowałyby jej przestrzeganie w praktyce poprzez wdrożenie procedur zapewniających realizację zobowiązań przewidzianych w tej dyrektywie, to polski ustawodawca, dokonując implementacji jej postanowień do polskiego porządku prawnego, nie uchwalił jednak żadnych przepisów, które szczegółowo określiłyby sposób jej wykonania. Państwowa Inspekcja Pracy była w ówczesnym stanie prawnym — szczególnie gdy spojrzy się na zakres jej kompetencji - organem kontrolnym, który w rzeczywistości nie miał faktycznych możliwości na podjęcie czynności zmierzających do weryfikacji, czy podmiot zagraniczny delegujący swojego pracownika na terytorium Polski zapewniał mu minimalne warunki zatrudnienia, zgodnie z obowiązkiem wskazanym w art. $67^{2}$ k.p. Najczęstszymi utrudnieniami działań inspektorów w tym zakresie były brak możliwości nawiązania kontaktu z pracodawcą delegującym (co do zasady przebywającym za granicą) bądź jakimkolwiek jego przedstawicielem oraz brak do- 
stępu do dokumentów związanych z zatrudnieniem pracowników delegowanych, umożliwiających ocenę stopnia wywiązywania się przez pracodawcę delegującego z obowiązków nałożonych na niego przepisami polskiego prawa. Tym samym regulacja materialnoprawna zawarta w przepisach art. $67^{1}$ i $67^{2}$ k.p. była niewystarczająca, a ochrona pracowników delegowanych do Polski — ze względu na brak instrumentów prawnych do egzekwowania wskazanej regulacji — miała charakter iluzoryczny.

Dyrektywa podstawowa obligowała ponadto państwa członkowskie do powołania biura łącznikowego oraz do ustanowienia mechanizmów współpracy administracyjnej między organami nadzoru nad warunkami pracy. Realizując postanowienia art. 4 dyrektywy 96/71/WE, Państwową Inspekcję Pracy ustanowiono jedną z instytucji łącznikowych (liaison office), czyli urzędów umocowanych do bezpośredniego komunikowania się ze swoimi odpowiednikami w krajach Unii Europejskiej, Europejskiego Obszaru Gospodarczego oraz Konfederacji Szwajcarskiej. Pierwotnie, od dnia wejścia Polski do Unii Europejskiej, Państwową Inspekcję Pracy zobowiązano do realizowania zadań instytucji właściwej do informowania, na pisemny wniosek, o minimalnych warunkach zatrudnienia pracowników, w zakresie wynikającym z przepisów działu drugiego rozdziału IIa kodeksu pracy ${ }^{20}$. Następnie, kolejną nowelizacją ustawy o Państwowej Inspekcji Pracy, wchodzącą w życie od dnia 5 maja 2005 roku $^{21}$, na Inspekcję Pracy nałożono obowiązek współpracy z urzędami państw członkowskich Unii Europejskiej, odpowiedzialnymi za nadzór nad warunkami pracy i zatrudnienia pracowników, polegającej na:

- udzielaniu informacji o warunkach zatrudnienia pracowników skierowanych do wykonywania pracy na terytorium państwa członkowskiego Unii Europejskiej na określony czas przez pracodawcę mającego siedzibę na terytorium Rzeczypospolitej Polskiej;

- informowaniu o stwierdzonych wykroczeniach przeciwko prawom pracowników skierowanych do wykonywania pracy na terytorium Rzeczypospolitej Polskiej na określony czas przez pracodawcę mającego siedzibę w państwie będącym członkiem Unii Europejskiej;

— wskazywaniu organu nadzoru nad rynkiem pracy, właściwego do udzielania żądanej informacji ze względu na zakres jego działania.

Obowiązki te nałożono na Państwową Inspekcję Pracy także nową ustawą z dnia 13 kwietnia 2007 roku o Państwowej Inspekcji Pracy ${ }^{22}$, która weszła w ży-

20 Art. 8 ust. 1 pkt 11c ustawy z dnia 6 marca 1981 roku o Państwowej Inspekcji Pracy (Dz.U. z 2001 r. Nr 124, poz. 1362) dodany przez art. 2 ustawy z dnia 14 listopada 2003 roku o zmianie ustawy Kodeks pracy oraz o zmianie niektórych innych ustaw (Dz.U. z 2003 r. Nr 213, poz. 2081) z dniem uzyskania przez Rzeczpospolitą Polską członkostwa w Unii Europejskiej.

21 Art. 8 ust. 1 pkt 11d ustawy z dnia 6 marca 1981 roku o Państwowej Inspekcji Pracy dodany przez art. 1 ustawy z dnia 16 lutego 2005 roku (Dz.U. z 2005 r. Nr 64, poz. 564) zmieniającej niniejszą ustawę z dniem 5 maja 2005 roku.

22 Dz.U. z 2007 r. Nr 89, poz. 589, dalej: ustawa o PIP. 
cie z dniem 1 lipca 2007 roku. Urząd ten został ponadto zobowiązany do współpracy z organami właściwymi innych krajów UE/EOG i Szwajcarii w zakresie wymiany informacji na temat delegowania, w szczególności poprzez udzielanie odpowiedzi na wnioski instytucji kontrolnych innych państw europejskich.

Po wejściu w życie ustawy o delegowaniu pracowników zakres obowiązków i uprawnień PIP w zakresie delegowania został przeniesiony do rozdziału 4 tej ustawy. Zadania Państwowej Inspekcji Pracy wyartykułowane tą ustawą koncentrują się w trzech zasadniczych obszarach:

— działalności PIP jako organu właściwego — udzielanie, na wniosek zainteresowanego, informacji o warunkach zatrudnienia oraz o zakresie ich stosowania do pracownika delegowanego na terytorium RP, współpraca z właściwymi organami innych państw członkowskich polegająca w szczególności na udzielaniu właściwemu organowi informacji o warunkach zatrudnienia pracowników delegowanych na terytorium RP i informowaniu właściwego organu o stwierdzonych nieprawidłowościach związanych z delegowaniem pracownika do albo z Polski, a także o wykroczeniach związanych z delegowaniem pracowników, występowaniu do właściwego organu z uzasadnionym wnioskiem o udzielenie informacji dotyczących delegowania pracowników do lub z RP bądź też o przeprowadzenie kontroli, udzielaniu niezbędnych informacji dotyczących delegowania pracowników na terytorium Rzeczypospolitej Polskiej albo z tego terytorium w odpowiedzi na uzasadnione wnioski właściwych organów, a także na przeprowadzaniu kontroli na wniosek takich organów oraz prowadzenie i aktualizacja strony internetowej, zawierającej najistotniejsze informacje dotyczące delegowania pracowników w ramach świadczenia usług oraz dane osoby odpowiedzialnej w PIP za udzielanie takich informacji;

- organu odpowiedzialnego za kontrolę — zadania kontrolne prowadzone są w dwóch zasadniczych strefach — weryfikacji, czy pracownik delegowany na teren Polski może w rzeczywistości zostać uznany za pracownika delegowanego, to jest czy spełnione są tak zwane kryteria delegowania, oraz badania spełniania przez pracodawcę delegującego pracowników na terytorium RP obowiązku zapewnienia tym pracownikom minimalnych warunków zatrudnienia wskazanych w art. 4 ust. 2 ustawy o delegowaniu pracowników. Natomiast kontrola przestrzegania przez polskich pracodawców delegujących przepisów prawa kraju oddelegowania pozostaje w kompetencjach służb i instytucji kontrolnych tych krajów. Organy Państwowej Inspekcji Pracy nie mają kompetencji do egzekwowania na rzecz polskich pracowników warunków zatrudnienia wynikających z ustawodawstwa innego niż polskie;

— transgranicznej egzekucji kar — zadania PIP dotyczą powiadamiania, na wniosek organu wnioskującego, pracodawcy delegującego pracowników z terenu Polski o decyzji w sprawie nałożenia na niego kary administracyjnej bądź grzywny albo o wniosku o egzekucję takiej kary lub grzywny, nałożonej w związku ze stwierdzonymi przez organ kontroli kraju przyjmującego nieprawidłowościami związanymi z delegowaniem. 
Instrumentem umożliwiającym sprawną wymianę informacji między państwami członkowskimi, którego stosowanie zostało narzucone przez dyrektywę wdrożeniową, jest konieczność wykorzystywania przy owej współpracy Systemu Wymiany Informacji na Rynku Wewnętrznym — IMI.

Działalność PIP jako organu właściwego odbywa się także — zgodnie z obowiązkiem nałożonym ustawą o delegowaniu pracowników — za pośrednictwem strony internetowej, na której publikowane są podstawowe informacje dotyczące minimalnych warunków zatrudnienia oraz zakresu ich stosowania.

Strona internetowa została uruchomiona we współpracy z ówczesnym Ministerstwem Rozwoju i prowadzona jest w ramach tak zwanego Punktu Informacji dla Przedsiębiorcy (pojedynczy punkt kontaktowy) zarówno w języku polskim, jak i angielskim.

Najważniejszą kompetencją Państwowej Inspekcji Pracy w zakresie delegowania pracowników na teren Rzeczypospolitej Polskiej jest bezsprzecznie możliwość prowadzenia kontroli podmiotów zagranicznych kierujących pracowników do wykonywania pracy na terytorium Polski. Jak już wspominano, kontrola ta odbywa się w dwóch podstawowych zakresach:

- weryfikacji, czy pracodawcę kierującego pracownika do pracy na terytorium Polski można uznać za pracodawcę delegującego, a pracownika — za pracownika delegowanego;

- sprawdzenia, czy pracownikom delegowanym na teren naszego kraju zapewniono przynajmniej minimalne warunki zatrudnienia gwarantowane polskimi przepisami.

Kontrola w zakresie weryfikacji wypełnienia przez podmiot zagraniczny tak zwanych kryteriów delegowania służy między innymi ustaleniu, czy w rzeczywistości pracodawca skierowujący pracownika może korzystać z pewnych „,korzyści” płynących z instytucji delegowania, wśród których należy wskazać na przykład możliwość utrzymania pracownika w systemie zabezpieczenia społecznego kraju wysyłającego.

„Dyrektywa wdrożeniowa” jasno precyzuje środki i metody kontroli, które mogą zostać wykorzystane w celu zbadania, czy pracownik delegowany może zostać uznanym za takiego. Najważniejszymi kryteriami delegowania, poddawanymi ocenie w toku kontroli, są:

— fakt prowadzenia znaczącej działalności przez pracodawcę delegującego w kraju wysyłającym;

- tymczasowość wykonywania pracy przez pracownika skierowanego do pracy na terenie Rzeczypospolitej Polskiej.

W ramach przyznanych przez dyrektywę wdrożeniową kompetencji w zakresie dokonywania powyższych ustaleń, przeniesionych następnie do ustawodawstwa krajowego w postaci art. 14 ustawy o delegowaniu pracowników w ramach świadczenia usług, organ kontrolny PIP dokonuje — w jak najszerszym horyzoncie czasowym - oceny wszelkich okoliczności, które cechują działalność prowadzo- 
ną przez pracodawcę delegującego, zarówno w kraju pochodzenia, jak i na terenie Rzeczypospolitej Polskiej. Do okoliczności tych należą w szczególności:

- miejsce, w którym przedsiębiorca ma zarejestrowaną działalność, prowadzi obsługę administracyjną, korzysta z pomieszczeń biurowych, podlega obowiązkom podatkowym z tytułu prowadzonej działalności i obowiązkom z tytułu ubezpieczeń społecznych oraz — tam, gdzie jest to wymagane — w którym, zgodnie z prawem państwa członkowskiego siedziby przedsiębiorcy, posiada stosowny dokument uprawniający do prowadzenia działalności danego rodzaju lub jest zarejestrowany w izbach handlowych lub organizacjach branżowych;

— miejsce, w którym prowadzi się nabór pracowników delegowanych i z którego są oni delegowani;

— prawo właściwe dla umów zawieranych przez pracodawcę delegującego pracownika ze swoimi pracownikami oraz prawo właściwe dla umów zawieranych z klientami tego pracodawcy;

— miejsce, w którym przedsiębiorca zatrudnia personel administracyjny;

— liczba wykonanych umów lub wielkość obrotu uzyskanego w państwie członkowskim siedziby przedsiębiorcy.

Natomiast w odniesieniu do pracownika delegowanego organ kontroli PIP będzie poddawał ocenie okoliczności cechujące pracę i sytuację danego pracownika delegowanego, w szczególności:

- wykonywanie pracy przez ograniczony okres na terytorium Rzeczypospolitej Polskiej,

— datę rozpoczęcia delegowania;

- delegowanie pracownika do państwa członkowskiego innego niż państwo, w którym ten pracownik zwyczajowo wykonuje swoją pracę;

- powrót pracownika do państwa członkowskiego, z którego został delegowany, lub przewidywanie, że ponownie podejmie on pracę w tym państwie po zakończeniu wykonywania pracy lub usług, do których wykonania został delegowany;

- charakter pracy;

— zapewnienie pracownikowi transportu, zakwaterowania i wyżywienia lub zwrot kosztów, a w przypadku ich zapewnienia lub zwrotu kosztów - sposób, w jaki jest to zapewniane, lub metoda, jaka jest stosowana przy zwrocie kosztów;

- wykonywanie pracy w poprzednich okresach na danym stanowisku przez tego samego lub innego pracownika.

W celu dokonania tych ustaleń, szczególnie w zakresie charakteru i skali działalności prowadzonej przez pracodawcę delegującego w kraju wysyłającym, Państwowa Inspekcja Pracy ma prawo wystąpić do organu właściwego kraju wysyłającego z wnioskiem o udzielenie informacji dotyczących delegowania pracowników na terytorium Rzeczypospolitej Polskiej lub o przeprowadzenie kontroli w tym zakresie. Współpraca z organami właściwymi krajów wysyłających odbywa się za pośrednictwem wspomnianego już Systemu Wymiany Informacji na Rynku Wewnętrznym — IMI. 
Kontrole pracodawców delegujących pracowników na terytorium RP przeprowadzane przez Państwową Inspekcję Pracy nie mogą mieć charakteru dyskryminującego ani nie mogą być nieproporcjonalne.

W sytuacji stwierdzenia przez organ kontroli Państwowej Inspekcji Pracy braku przesłanek do uznania pracownika za pracownika delegowanego organowi temu przysługuje prawo wniesienia do sądu powództwa o ustalenie prawa właściwego dla stosunku pracy łączącego tego pracownika i jego pracodawcę.

Ustawa o delegowaniu pracowników usunęła ułomność prawa, jaką był rzeczywisty brak możliwości weryfikacji, czy pracodawca delegujący pracowników na teren Rzeczypospolitej Polskiej zapewnia im minimalne warunki zatrudnienia. Wprowadziła ona wiele rozwiązań, które umożliwiają organom kontrolnym Państwowej Inspekcji Pracy prowadzenie kontroli zagranicznych przedsiębiorców delegujących swoich pracowników na terytorium Rzeczypospolitej Polskiej. Co najważniejsze, w konsekwencji uchwalenia ustawy o delegowaniu pracowników znowelizowano także artykuł 13 ustawy o PIP, do którego wprowadzono punkt 4, stanowiący, że kontroli Państwowej Inspekcji Pracy w zakresie określonym w ustawie z dnia 10 czerwca 2016 roku o delegowaniu pracowników w ramach świadczenia usług podlegają pracodawcy delegujący pracowników na terytorium RP.

Wśród podstawowych narzędzi umożliwiających wypełnienie przez organy kontroli PIP obowiązków kontrolnych w zakresie badania przestrzegania przez pracodawców delegujących minimalnych warunków zatrudnienia znajduje się zobowiązanie pracodawców delegujących swoich pracowników na terytorium RP do informowania inspekcji o fakcie delegowania. Pracodawcy zagraniczni kierujaccy do Polski podległych im pracowników są zobligowani do sporządzenia tak zwanego Oświadczenia o delegowaniu. Oświadczenie to musi zostać przekazane do Głównego Inspektoratu Pracy najpóźniej w dniu rozpoczęcia świadczenia usługi i musi być też każdorazowo aktualizowane w wypadku zmiany danych dotyczących podmiotu delegującego. Ułomnością wprowadzonego rozwiązania jest brak obowiązku aktualizacji oświadczenia w wypadku zmian informacji dotyczących pracowników delegowanych, w tym okresu ich delegowania. W konsekwencji organy kontroli PIP nie mają pełnej, aktualnej wiedzy odnośnie do rzeczywistej liczby pracowników delegowanych na teren Polski, co znacznie utrudnia działania kontrolne.

Ustawa o delegowaniu pracowników wprowadza także obowiązek wyznaczenia przez pracodawcę delegującego na terytorium Polski osoby uprawnionej do kontaktu z Państwową Inspekcją Pracy oraz obowiązek przechowywania i udostępniania w terminie pięciu dni — wraz z ich tłumaczeniem — dokumentów związanych z pracą powierzaną pracownikom delegowanym. Choć praktyka inspektorska potwierdza, że nie wszyscy pracodawcy składają oświadczenie o delegowaniu (zdecydowanie częściej nie wypełniają tego obowiązku pracodawcy z krajów trzecich), to generalnie należy ocenić, że wprowadzenie tych trzech obowiązków wobec pracodawców delegujących znacznie wpłynęło na możliwość 
prowadzenia kontroli zagranicznych podmiotów delegujących oraz efektywność tych czynności.

Pośród instrumentów umożliwiających skuteczniejszą realizację obowiązku współpracy z organami właściwymi krajów członkowskich, rozumianego jako udzielanie odpowiedzi na ich umotywowane wnioski dotyczące delegowania pracowników na bądź z terytorium Rzeczypospolitej Polskiej, w tym także przeprowadzanie kontroli w celu uzyskania danych niezbędnych do sporządzenia takiej odpowiedzi, należy wskazać przepisy art. 12 tejże ustawy.

Przyznanie organom Państwowej Inspekcji Pracy uprawnienia do żądania od pracodawców delegujących pracowników z terytorium Rzeczypospolitej Polskiej oraz od niebędących pracodawcami przedsiębiorców (w rozumieniu ustawy Prawo Przedsiębiorców ${ }^{23}$ ) udzielenia informacji dotyczących ich działalności, niezbędnych do sporządzenia przez PIP odpowiedzi na wniosek instytucji łącznikowej państwa członkowskiego, umożliwia inspektorom pracy podjęcie czynności jednakże niebędących kontrolą — wobec podmiotów delegujących, które do tej pory nie podlegały kontroli PIP, to jest głównie wobec podmiotów, które utraciły już status podmiotu kontrolowanego ze względu na zaprzestanie powierzania pracy. Przepis ten umożliwia ponadto wnioskowanie o udzielenie informacji objętych wnioskiem instytucji łącznikowych do Zakładu Ubezpieczeń Społecznych, naczelników właściwych urzędów skarbowych oraz innych organów administracji publicznej, zakreślając jednocześnie maksymalny, dziesięciodniowy termin na udzielenie odpowiedzi na taki wniosek. Ze względu na narzucony dyrektywą wdrożeniową, a następnie implementowany do ustawy o delegowaniu termin na udzielenie odpowiedzi wnioskującej stronie z państwa członkowskiego, który wynosi maksymalnie 25 dni, należy uznać owo rozwiązanie za wyjątkowo służące zwiększeniu efektywności realizacji obowiązku nałożonego na Państwową Inspekcję Pracy.

Zgodnie z treścią art. 15 ust. 2 ustawy o delegowaniu pracowników w ramach świadczenia usług organom kontroli PIP przyznano uprawnienie do stosowania środków prawnych, o których mowa w art. 11 ustawy o Państwowej Inspekcji Pracy, w zakresie warunków pracy pracowników delegowanych. W ustawie nie wyrażono natomiast w sposób jasny i bezsprzeczny prawa zastosowania przez inspektora pracy środków prawnych w wypadku niewypełnienia przez pracodawcę delegującego tak zwanych obowiązków informacyjnych, czyli tych obowiązków, których realizacja w rzeczywistości implikuje możliwość prowadzenia kontroli w obszarze delegowania. Uwzględniając ważność charakteru obowiązków wyartykułowanych $\mathrm{w}$ art. 25 ustawy o delegowaniu pracowników w ramach świadczenia usług, wydaje się, że posiłkowo należy uznać, iż skoro ustawa ta jest aktem prawnym z zakresu prawa pracy, a jednocześnie PIP jest organem powołanym do

23 Ustawa z dnia 6 marca 2018 roku - Prawo przedsiębiorców (Dz.U. z 2018 r. poz. 646, 1479, 1629 i 1633). 
sprawowania nadzoru i kontroli przepisów prawa pracy (art. 1 ustawy o Państwowej Inspekcji Pracy), to w ramach kompetencji nadzorczych organów PIP możliwe jest regulowanie nieprawidłowości w zakresie tychże obowiązków informacyjnych dostępnymi środkami prawnymi pozostającymi w dyspozycji organu kontroli ${ }^{24}$.

Przepisy ustawy o delegowaniu pracowników przyznają organom kontroli PIP uprawnienie karania pracodawców delegujących pracowników na teren Polski. Za nieprzestrzeganie minimalnych warunków zatrudnienia ustalonych przepisami polskiego prawa pracy zagraniczni pracodawcy delegujący ponoszą odpowiedzialność na równi z polskimi pracodawcami, zgodnie z właściwymi przepisami ustawy - Kodeks pracy ${ }^{25}$. Natomiast za naruszenie obowiązków pracodawcy delegującego, w tym obowiązków informacyjnych wobec PIP, pracodawca delegujący bądź osoba działająca w jego imieniu odpowiada karnie na mocy przepisów ustawy o delegowaniu 26 .

Niestety doświadczenia inspektorów pracy prowadzących kontrole w zakresie delegowania pracowników na teren Polski wskazują, że mające w tym wypadku zastosowanie przepisy ustawy z dnia 24 sierpnia 2001 roku - Kodeks postępowania w sprawach o wykroczenia ${ }^{27}$ okazują się nieskuteczne. W rzeczywistości nie ma realnej możliwości pociągnięcia do odpowiedzialności zagranicznego pracodawcy ze względu na to, że co do zasady pracodawcy ci nie przebywają na terytorium Polski, co uniemożliwia inspektorowi pracy nałożenie na takiego pracodawcę grzywny w drodze mandatu karnego, dotychczasowa praktyka zaś pokazuje, że brak krajowego adresu do korespondencji jest głównym powodem nieprzyjęcia przez sądy wniosku o ukaranie, sporządzonego przez inspektora pracy wobec zagranicznego pracodawcy. Rozwiązaniem takiej sytuacji — stosowanym w wielu krajach członkowskich - byłoby umożliwienie sankcjonowania naruszeń przepisów przedmiotowej ustawy w trybie kar pieniężnych i grzywien administracyjnych, co jednocześnie pozwoliłoby polskim organom korzystać z przewidzianych dyrektywą wdrożeniową instrumentów transgranicznej egzekucji kar.

24 Ocena rozwiazań prawnych zawartych w ustawie z dnia 10 czerwca 2016 r. o delegowaniu pracowników w ramach świadczenia usług w świetle działań kontrolno-nadzorczych PIP realizowanych w latach 2016-2017 i wspótpracy z organami kontrolnymi innych krajów europejskich materiał wewnętrzny Państwowej Inspekcji Pracy opracowany na posiedzeniu Komisji ds. Kontroli Państwowej, kwiecień 2018.

25 Art. 281-283 ustawy z dnia 26 czerwca 1974 roku — Kodeks pracy (Dz.U. z 2018 r. Nr 917 ze zm. oraz z 2018 r. poz. 2245).

26 Art. 27-28 ustawy z dnia 10 czerwca 2016 roku o delegowaniu pracowników w ramach świadczenia usług (Dz.U. z 2018 r. poz. 2206).

27 Ustawa z dnia 24 sierpnia 2001 roku - Kodeks postępowania w sprawach o wykroczenia (Dz.U. z 2018 r. poz. 475). 


\section{PODSUMOWANIE}

Dzięki implementowaniu do polskiego systemu prawnego dyrektywy wdrożeniowej 2014/67/UE poprzez uchwalenie ustawy o delegowaniu pracowników w ramach świadczenia usług Państwowa Inspekcja Pracy zyskała niewątpliwie akt prawny, w sposób kompleksowy regulujący tematykę delegowania pracowników na teren Rzeczypospolitej i kontroli zagranicznych podmiotów korzystających poprzez delegowanie pracowników ze swobody świadczenia usług.

Jednak doświadczenia kontrolne ostatnich lat wskazują, że polskie przepisy w tym zakresie, choć implementowane w całości, wymagają zmian i pewnego dookreślenia. Państwowa Inspekcja Pracy postuluje wprowadzenie konkretnych rozwiązań, które nie tylko usprawnią (czy wręcz w wielu wypadkach umożliwią) prowadzenie kontroli, lecz które także pozytywnie wpłyną na poziom praworządności w tym zakresie. Wśród tych postulatów znajdują się między innymi wnioski o wyraźne wskazanie możliwości stosowania przez inspektorów pracy środków prawnych w związku z niewypełnieniem przez pracodawców obowiązków informacyjnych, wskazanie w przepisach ustawy trybu postępowania w wypadku złożenia niekompletnego oświadczenia o delegowaniu bądź w wypadku zmiany stanu faktycznego w nim wskazanego czy wreszcie umożliwienie sankcjonowania naruszeń przepisów ustawy w trybie decyzji administracyjnych, poddawanych transgranicznej egzekucji kar, w miejscu dotychczasowego postępowania w sprawach o wykroczenia.

Należy jednak mieć na uwadze, że z jednej strony ustawa o delegowaniu pracowników jest aktem dość niedawnym, co powoduje, że praktyka jej stosowania nie została jeszcze ostatecznie ukształtowana, z drugiej zaś, że 29 lipca 2018 roku weszła w życie nowelizacja dyrektywy podstawowej o delegowaniu, która przewiduje dwuletni okres dostosowawczy, w trakcie którego państwa członkowskie muszą przyjąć rozwiązania prawne implementujące do krajowych porządków nowe przepisy. Niechybnie oznacza to, że nastąpią zmiany prawnych regulacji odnoszących się do delegowania pracowników i transgranicznego świadczenia usług, a problematyka delegowania będzie często powracała jako przedmiot prawniczych rozważań.

Okres ten będzie też czasem, w którym polscy pracodawcy delegujący pracowników będą musieli podjąć działania przystosowawcze do nadchodzącej nowej rzeczywistości, która znacznie ograniczy ich dotychczasową konkurencyjność. Jak prognozują najwięksi pesymiści, owa nowa rzeczywistość może nawet zmusić przedsiębiorców do rezygnacji z instytucji delegowania pracowników i postawi ich przed koniecznością przeniesienia działalności poza granice naszego kraju. 


\title{
POSTING OF WORKERS IN THE FRAMEWORK OF THE PROVISION OF SERVICES. THE ROLE OF THE NATIONAL LABOR INSPECTORATE AS „A COMPETENT BODY” IN THE MEANING OF DIRECTIVE 2014/67/WE AND OTHER PIP TASKS IN THE AREA OF POSTING OF WORKERS
}

\begin{abstract}
Summary
The article seeks to familiarize the reader with the phenomenon of the posting of workers in the framework of the provision of services, with particular emphasis placed on the differences between posting and a business trip. Explaining these differences seems to be of paramount importance in the case of workers posted from the territory of Poland to work abroad as implementation of business trip procedures in a situation of actual posting often leads to the circumventing of legal regulations on social security and personal income tax - deliberately and voluntarily or entirely by accident - and, consequently, to a reduction of the inflow of the amounts due to the state budget.

This paper also presents an issue which is inseparably linked with posting, i.e. minimum employment conditions in a host country which must be guaranteed - irrespective of the choice of law made by the parties to the legal relationship — by the employer posting a worker outside the territory of the country where he/she usually performs work.

The posting of workers in the framework of the provision of services falls within the area of the labour law regulated by the intracommunity standards which have been implemented in the Polish legal system. The article discusses the main EU legal acts pertaining to this matter and how these regulations have been introduced in the Polish law by means of the Act on of 10 June 2016 on the posting of workers in the framework of the provision of services.

When analyzing the contents of the above-mentioned Act, a reference has been made to the National Labour Inspectorate's remit, as per the provisions of the Act, as "a competent body" in the meaning of Directive 2014/67/EU, as well as to other tasks, obligations and rights of this institution resulting from the legal regulations in the area of the posting of workers in the framework of the provision of services.

The remarks made in this article, presented in view of the legislation in force, lead to conclusions as regards necessary amendments of legal provisions on the competence and remit of the National Labour Inspectorate as the authority appointed to ensure the rule of law in the area of the posting of workers.
\end{abstract}

Keywords: posting of workers, terms and conditions of employment, liaison office and competent national body, administrative cooperation, inspections

\section{BIBLIOGRAFIA}

Dokument roboczy służb Komisji Impact Assessment. Revision of the legislative framework on the posting of workers in the context of provision of services $\mathrm{z}$ dnia 21 marca 2012 roku, SWD(2012) 63.

Komunikat Komisji Europejskiej z dnia 4 kwietnia 2006 roku Wytyczne dotyczace delegowania pracowników w ramach świadczenia ustug", COM 2006, nr 159.

Mitrus L., Charakter prawny delegowania pracowników w ramach swobody świadczenia ustug w Unii Europejskiej, „Europejski Przegląd Sądowy”, czerwiec 2018.

Ocena rozwiazań prawnych zawartych $w$ ustawie z dnia 10 czerwca 2016 r. o delegowaniu pracowników $w$ ramach świadczenia ustug $w$ świetle działań kontrolno-nadzorczych PIP rea- 
lizowanych w latach 2016-2017 i wspótpracy z organami kontrolnymi innych krajów europejskich" - materiał wewnętrzny Państwowej Inspekcji Pracy opracowany na posiedzeniu Komisji ds. Kontroli Państwowej, kwiecień 2018.

Osiński Ł., Protekcjonizm zachodniej Europy w kończacej się kadencji PE podzielit UE, Polska Agencja Prasowa, https://www.pap.pl/aktualnosci/news,457657,protekcjonizm-zachodniej-europy-w-konczacej-sie-kadencji-pe-dzielil-ue.html?fbclid=IwAR0kNq28ucah6K9UND4 Y8mW9mjmt0Y93g3A6r-NugSVSwYfN2Ita4gNPs7A.

Tomaszewska M., Delegowanie pracowników - w poszukiwaniu równowagi między swoboda świadczenia ustug a ochrona praw pracownika, „Europejski Przegląd Sądowy” czerwiec 2018.

\section{AKTY PRAWNE}

Dyrektywa 96/71/WE Parlamentu Europejskiego i Rady z dnia 16 grudnia 1996 roku dotycząca delegowania pracowników w ramach świadczenia usług, Dz. Urz. WE L 18 z 21 stycznia 1997 r., Dz. Urz. UE, polskie wydanie specjalne, rozdz. 5, t. 2.

Dyrektywa Parlamentu Europejskiego i Rady 2014/67/UE z dnia 15 maja 2014 roku w sprawie egzekwowania dyrektywy 96/71/WE dotyczącej delegowania pracowników w ramach świadczenia usług, zmieniająca rozporządzenie (UE) nr 1024/2012 w sprawie współpracy administracyjnej za pośrednictwem systemu wymiany informacji na rynku wewnętrznym („,rozporządzenie w sprawie IMI"), Dz. Urz. UE L 159 z 28 maja 2014 r.

Dyrektywa Parlamentu Europejskiego i Rady 2018/957 z dnia 28 czerwca 2018 roku zmieniająca dyrektywę 96/71/WE dotyczącą delegowania pracowników w ramach świadczenia usług; Dz.U. UE L z 2018 r., 173/16, wydanie polskie.

Wersje skonsolidowane Traktatu o Unii Europejskiej i Traktatu o funkcjonowaniu Unii Europejskiej, Dz. Urz. UE C 202 z 2016 r., t. 56 z 7 czerwca 2016 r.

Ustawa z dnia 26 czerwca 1974 roku — Kodeks pracy (Dz.U. z 2018 r. Nr 917 ze zm. oraz z 2018 r. poz. 2245).

Ustawa z dnia 24 sierpnia 2001 roku — Kodeks postępowania w sprawach o wykroczenia (Dz.U. z 2018 r. poz. 475).

Ustawa z dnia 14 listopada 2003 roku o zmianie ustawy Kodeks pracy oraz o zmianie niektórych innych ustaw (Dz.U. z 2003 r. Nr 213, poz. 2081).

Ustawa z dnia 16 lutego 2005 roku o zmianie ustawy o Państwowej Inspekcji Pracy (Dz.U. z 2005 r. $\mathrm{Nr} 64$, poz. 564).

Ustawa z dnia 13 kwietnia 2007 roku o Państwowej Inspekcji Pracy (Dz.U. z 2018 r. poz. 623 ze zm. oraz z 2018 r. poz. 2282).

Ustawa z dnia 10 czerwca 2016 roku o delegowaniu pracowników w ramach świadczenia usług (tekst jedn. Dz.U. z 2018 r. poz. 2206).

Ustawa z dnia 6 marca 2018 roku — Prawo przedsiębiorców (Dz.U. z 2018 r. poz. 646, 1479, 1629 i 1633).

\section{ORZECZNICTWO}

Uchwała Sądu Najwyższego z dnia 19 listopada 2008 roku, II PZP 11/08. Wyrok Sądu Najwyższego z dnia 22 lutego 2008 roku, I PK 208/07.

Wyrok Sądu Najwyższego z dnia 3 grudnia 2009 roku, II PK 138/09.

Wyrok Sądu Najwyższego z dnia 14 listopada 2013 roku, II UK 204/13.

Wyrok Trybunału Sprawiedliwości z dnia 18 grudnia 2007 roku, C-341/05, Laval un Partneri przeciwko Svenska Byggnadsarbetareförbundet, Svenska Byggnadsarbetareförbundets avdelning 1, Byggettan i Svenska Elektrikerförbundet, EU:C:2007:809. 